\title{
Implicit Ideological and Political Education Pattern of Higher Learning Institution Analysis
}

\author{
Yixia HE \\ Nanyang Medical College \\ Nanyang,473058 China
}

\begin{abstract}
Implicit ideological and political education refers conscious use of the hidden curriculum theory in the process, focusing on the development and utilization of resources implicit ideological and political education, through more subtle forms, making the educator unconsciously get some kind of thoughts among the education experience. In practice, the effective use of college students recessive mode of ideological and political education and students recessive mode of maximum function, we should focus on the development of implicit ideological and political education resources about these three aspects.
\end{abstract}

Keywords- university students; implicit ideological and political education; mode

\section{INTRODUCTION}

Currently, under the background that student's subject awareness increases, the degree of socialization increasing, social influence diversified increasing, single dominant mode of education can not meet the actual needs of the ideological and political education, resulting in a certain degree of ideological and political education effect on reducing or even failure. In this case, the implicit ideological and political education as an educational theory and educational methods and complementary dominant ideological and political education, more and more emphasis on education and more widespread use the ideological and political education of college students.

\section{CONNOTATION AND FORM OF RECESSIVE IDEOLOGICAL AND POLITICAL EDUCATION}

The so-called implicit ideological and political education is opposed to the dominant ideological and political education, referring to the process of ideological and political education in the conscious use of the hidden curriculum theory, focusing on the development and utilization of resources implicit ideological and political education, through more subtle form, making the educator unconsciously get some kind of thoughts among the education experience. Implicit ideological and political education has an indirect, effective, arbitrary educational process, education and educational way to open the main characteristics of autonomy. Recessive ideological and political education helps to improve the education of students in the process of personality, cultivate the students' sentiments, and regulate student behavior, to achieve allround development of college students, which is an effective way for indispensable ideological and political education. In general, university implicit ideological and political education includes three basic forms: the physical environment of the university campus as the carrier material form implicit ideological and political education; institutional forms to manage the school system as a carrier of the recessive ideological and political education university spirit as the carrier of the recessive form of the spirit of the ideological and political education.

\section{CONSTRUCTION OF StUdENTS' RECESSIVE MODE OF IDEOLOGICAL AND POLITICAL EDUCATION}

The so-called recessive mode of ideological and political education refers to a form of implicit ideological and political theory in college students with hands-on research and education in cross germinal which is simple, clear structure, can be funded emulate the promotion of ideological and political education paradigm. Combined with practical work experience, I believe that the construction of ideological and political education of college students recessive mode of education should base on the principle mode of ideological and political education and the internal laws of the theoretical basis of ideological and political education of college students daily practice as the basis of experience, focusing on the clear goals, clarify the structure and three aspects of the planning process.

\section{A. Task and Goal of College Students' Implicit Ideological and Political Education}

Students' implicit ideological and political education as an effective form of ideological and political education, its objectives and tasks is generally consistent with mission objectives and the ideological and political education, and it is "to achieve a comprehensive development of college students," "morality and intelligence training body beauty socialism qualified builders and reliable successors of comprehensive development. "Meanwhile, college students implicit ideological and political education as a relatively independent and complete system help students to correct political outlook, values, ethics, inside view of life and the rule of law, with its own more specific and clear goals and 
tasks, namely the consolidation of political theory in the educational outcomes. The value of individual identity and conscious choice expand and extend into the ideological and political education area, improving the effectiveness of ideological and political education, giving full play to the ideological and political education of the daily educational function, forming a comprehensive pattern of college students' ideological and political education.

\section{B. The Basic Structure of College Students' Implicit Ideological and Political Education}

Students' implicit ideological and political education is an all interrelated and interacted system, educational subject, educational objects, educational support, educational content are the basic elements of the system. Compared with the traditional ideological and political education, the "four elements theory" (i.e., educational subject, educational objects, educational mediator, educational loop body), implicit ideological and political education specially emphasizes on highlighting the "educational support", emphasizes educational subject must depend on particular physical form, shape or spiritual education support system forms the educational content delivery or object penetration to education, which is the implicit ideological and political education was significantly different from the dominant symbol of ideological and political education, but also the implicit ideological and political education's characteristic structure lies.

\section{Operational Process of College Students' Recessive Ideological and Political Education}

Operational process of college students' recessive ideological and political education is center on achieving educational goals, completing educational elements and designing, arranging operational procedures and educational activities. Generally speaking, the ideological and political education of college students' recessive process roughly divides into the following five steps: first, the development of educational subjects. Based on the universality of the implicit ideological and political education, routine, its educational subject is far beyond the scope of ideological and political education, and all full-time workers, university faculty and staffs are possible and should become the main implicit ideological and political education. Therefore, the implementation of implicit ideological and political education college students must give priority to the development of education body, improve the overall educational awareness, clear staff responsibilities and obligations of ideological and political education, rely on the ideological and political education faculty will melt in specific classroom behavior, management behavior, behavior among service. Second is analyzing educational objects. Ideological education status object is the logical starting point implicit ideological and political education, in particular, the main ideological and political education of full-time workers must carefully research, analysis, track, grasp ideological education status and trends of the object, for the development of targeted implicit ideological and political education to provide evidence and advice, and truly make education "targeted" to prevent blind unprovoked "bombing." Third: the selection of educational support. Education refers to those carry and bear conduction of ideological and political education information can provide the use of ideological and political education and ideological and political education in the form of activities that educators and learners can take the interaction. With respect to the dominant ideological and political education "indoctrination" hidden ideological and political education more emphasis on "infiltration" and emphasized by means of specific carrier subtle, softly affect educational objects. Fourth: adding educational content. Educational support for natural objects can pass some information, but this information is passing under state education unconscious body, and does not belong to the scope of the implicit ideological and political education. Only in educational subject a conscious choice of educational content and educational content by adjusting for education support, after being re-poured into education support, educational support to pass information to the educational process really object into a recessive ideological and political education process. Fifth: the feedback of education effect. The effect of implicit ideological and political education has great uncertainty and uncontrollable, the educational subject, educational support and any other aspect of the deviation of the behavior that may lead to lower educational effect even zero effect, negative effect. Therefore, we must establish an effective educational effect feedback mechanism, the use of variable-control experiment, the education act and other scientific methods results traceable to strengthen ideological and political education recessive effect monitoring, timely adjustment and improvement.

\section{RESOURCE DEVELOPMENT OF STUDENTS RECESSIVE APPLICATION OF THE IDEOLOGICAL AND POLITICAL EDUCATION MODE}

Using of students' recessive mode of ideological and political education must rely on a particular carrier implicit ideological and political education, namely the implicit ideological and political education resources. The author believes that the effective use of college students' recessive mode of ideological and political education, ideological and political education has maximum function, and we should focus on the three aspects development of implicit ideological and political education of college material resources, institutions and spiritual.

\section{A. Pay Attention to the Implicit Ideological and Political Education Resource Development of University-level Material}

Material aspects of implicit ideological and political education university resources mainly refer to the physical environment of the campus (including campus planning, architectural design, natural and cultural landscape of the campus and campus ecological environment, etc.). Students' living on campus is a place of learning space, but the campus is not only as a "dead" material exists, it is used as a highlevel "live" which the soul of the storage and transfer of cultural and spiritual university, students can bring a strong 
and direct sensory stimulation. Reasonable value of the campus physical environment steeped in history, tradition, culture and society, carrying the truth Park, broad, thick university spirit, implies a huge potential educational value. Reasonable campus physical environment can influence students with its intuitive and ultra-language values, attitudes and moral emotions, help students unwittingly infected and nurtured so that students experience during university deeply unconscious solemn and profound, beneficial inspire students rationality, and it will motivate students, urging them to consciously cultivating, learning. Therefore, college students in the application of the recessive mode of ideological and political education in the process of education must attach great importance to the construction of the campus physical environment, pay attention to creating a positive, healthy school physical environment, give full play to the positive effects of the physical environment of the campus and the moral character of the ideological and moral.

\section{B. Pay attention to the implicit ideological and political education resource development of university-level institution}

Implicit ideological and political education in colleges and universities system level resources mainly refers to the school's management system (including the management of the projected system management concept, the use of management tools, etc.). Political recognition in school, students on the one hand is under specification constraint management system, on the other hand used "acquisition" approach derive ideological and political awareness, and unconsciously acquire knowledge from books, "learn" the ideological and political awareness inspection and comparison. In this process, a positive rational school management system for classroom indoctrination of political thought and ethics will play a positive role in consolidating and internalization, boosting thinking. Effectiveness political education; on the contrary, irrational school management system will be political and ideological indoctrination in the classroom and ethics from the reverse effect on digestion and externalization, reducing the effectiveness and efficiency of the ideological and political education, and even lead to ideological and political education zero effect or negative effect. Therefore, in the construction of university systems, with particular emphasis on the one hand to reflect the "law school" concept, in the process of developing the management system must give priority to the law, the "legal" or "illegal" in a prominent position, in strict accordance with the law the provisions of the development management system, and make sure the law, as much as possible to prevent management system appears unable to follow or inconsistent with the law of the phenomenon, the concept of the rule of law in order to train students to develop the habit of law-abiding students, shaping students act according to the law of character and self-discipline; on the other hand must emphasize reflecting the "democratic participation" concept, the creation of conditions to open up channels for students to participate in the democratic management of schools, education and practice of democracy, in order to enhance students 'awareness of democracy, enhance students' exercise the ability of democratic rights, and promote the process of political socialization of students.

\section{Pay attention to the implicit ideological and political education resource development of university spiritual}

Implicit ideological and political education college's spiritual resources including professional education, teacher demonstration, teacher-student relationship, campus culture and so on. The ideological and political education resources conveyed spiritual values, ideological quality, content literacy and other information directly affects the quality of ideas and moral development of students and the formation; good shape for its extensive campus spirit, spontaneity and permeability physical and mental health of college students have a positive growth promotion, guidance, constraints, norms and educational role. Implicit in the development of ideological and political education colleges spiritual resources in the process, should be mainly from the construction of the three aspects of professional education, teachers strive to carry out demonstrations and campus culture.

We need to develop the professional education resources in the implicit ideological and political education. Most professional education bears a lot of the ideological and political effective resource education. American philosopher and educator John Dewey pointed out that morality is the ultimate and the highest goal of education. Therefore, in the professional education, we must not one-sided emphasis on cultivating students' professional knowledge and skills that neglect of the ideological and moral shape, but not to the "timber" education fuzzy "adult" education must Ideological and political education, moral education in being professional education, in the course of professional education in the technology ethics, science ethics, humanities and other ideas and norms of behavior, such as taught to the younger generation, the "preaching, Tuition, FAQ" three good combination give full play to the ideological and political education support functions and infiltration professional education.

We need to develop campus value culture of implicit ideological education resource. Campus culture is an important part of college construction of spiritual civilization, and its goal is designed to educate people and ideological and political education work with a high degree of consistency. Campus culture positive physical and mental growth has been highly recognized by the majority of the ideological and political education workers.

\section{CONCLUSION}

Campus culture is student-centered, extra-curricular and cultural activities as the main content, and the main campus space is the campus spiritual core of cultural activities. Construction of excellent campus culture, give full play to the implicit ideological and political education of excellent campus culture, universities should plan, target to strengthen high-level construction of campus culture, promote campus culture to a higher level, by conducting student loved, colorful, positive academic, science and technology, sports, 
arts and entertainment activities, the construction of socialist culture and excellent national culture as the main body healthy and lively campus culture, and resolutely eliminate the "desk culture", "toilet culture", "wall culture" and other "counter-culture" phenomenon, efforts to purify the campus environment, and create a strong cultural atmosphere on campus, students with elegant cultural nourish mind, oppose and resist vulgar, vulgar, decadent culture and irrational tendency to guide the campus culture in a positive atmosphere, healthy direction.

\section{References:}

[1] [1] Liu Xiaofang. Implicit ideological and political education of college students. [J]. Contemporary Youth Research, 2006, (4).

[2] [2] Wang Hao. Hidden Moral Education. [J]. Ideological Education Research, 2006, (1).

[3] [3] Luo Hongtie, Dong Ya. Principles and methods of ideological and political education. [M]. Beijing: People's Publishing House, 2005.

[4] [4] The State Department of the CPC. Opinions on Further Strengthening and improving the ideological and political education. [N]. People's Daily, 2004-10-15 (1).

[5] [5] Zhang Yaocan, Zheng Yongting. Modern Ideological and Political Education. [M]. Beijing: People's Publishing House, 2001.

[6] [6] Chen Wanbai. Political and Ideological Education Theory. [M]. Wuhan: Hubei People's Publishing House, 2003. 